\title{
A Multi-Country Study of Cross-Border Transmission of Monetary Policy by IBRN
}

\author{
Konstantin Styrin, New Economic School, \\ Bank of Russia \\ kstyrin@nes.ru
}

\begin{abstract}
This short report surveys main findings of a recent multi-country research effort within the IBRN network. 17 national teams used confidential supervisory bank-level data to study international transmission of monetary policy changes in systemic countries into bank lending to private non-financial borrowers worldwide. Two channels of transmission, the bank funding channel and asset rebalancing channel, are tested separately. The effect of monetary policy changes in the US on domestic lending is statistically significant in most specifications. The economic significance of the estimated effect is relatively higher for more financially open economies and emerging markets.
\end{abstract}

Keywords: monetary policy, international spillovers, crossborder transmission

JEL: E52, F34, G01, G21
Citation: Styrin, K. (2018). A Multi-

Country Study of Cross-Border Transmission of Monetary Policy by IBRN. Russian Journal of Money and Finance, 77(2), pp. 81-94

doi: $10.31477 /$ rjmf.201802.81

\section{Introduction}

The International Banking Research Network (IBRN) is a research initiative that involves research teams of about 20 central banks all over the world coordinated by the Federal Reserve Bank of New York. ${ }^{1}$ Its objective is to study policy-related research questions using a common methodology and bank-level data. Each country's research team has an access to confidential bank financial statements that financial institutions are obliged to submit on the monthly/quarterly basis. These data are sensitive and therefore cannot be made public. The respective country's team though can employ these data for research purposes without need to disclose them. The fact that all teams use the same methodology makes country-specific findings comparable among each other, which makes it possible to draw a "big picture" with regard to the research question of interest.

\footnotetext{
${ }^{1}$ https://www.newyorkfed.org/ibrn
} 
The most recent IBRN project was about international transmission of monetary policy through banks. The research questions of interest are: 1) How do shifts in the monetary policy stance in the key economies - the United States, the United Kingdom, the euro zone, and Japan - affect the growth of lending in other countries? 2) What is the effect of changes in monetary policy in a home country on cross-border lending activities of home banks and the growth in local credit extended by their foreign affiliates?

There are several reasons why changes in monetary policy can transmit internationally affecting economic activity not only in the home country but also, potentially, overseas. One well familiar channel works through trade links: a monetary expansion at home stimulates demand for imports, which boosts the economic activity in the country's trade partners. This effect is partially offset by a depreciation of the home country's currency that typically accompanies monetary loosening. A few international transmission channels arise as a consequence of financial links between countries. This IBRN project focuses on two specific channels that work through bank balance sheets. The existing literature on the cross-border monetary transmission is surveyed in Buch et al (2018).

The first one is the so-called bank funding channel, a.k.a. international bank lending channel. In practice, banks can obtain funding for their lending and other activities not only from national sources, i.e. from domestic deposits and money market, but also internationally, e.g. by taking cross-border loans from foreign financial institutions. If such a loan is originated from a systemic country, say, the US, it is most likely denominated in the US dollars. A monetary tightening in the US will make dollar finding more expensive. Due to frictions, a bank is not able to immediately substitute the cross-border dollar loan by funds from domestic sources. The most likely response will be a reduction in the amount of dollar-denominated liabilities on the balance sheet of the bank, being, perhaps, only partially offset by a rise of liabilities denominated in the home currency. The direct cost effect is amplified by a depreciation of the home currency caused by the monetary tightening in the US if the fraction of dollardenominated liabilities exceeds the fraction of dollar-denominated assets, and this currency mismatch is not hedged, as the net worth of the bank declines forcing it to deleverage. The funding channel thus implies that a monetary tightening in the US will slow lending growth by home banks. The strength of this effect will vary across banks. It will be more pronounced for institutions with a high exposure to international funding: the more a bank relies on external borrowing, the more sensitive is the volume of its loan portfolio to changes in the US interest rate.

The second mechanism of international transmission related to bank balance sheets is the so-called portfolio channel. A monetary tightening in the US will depress the net worth of American borrowers, firms and households, for two reasons. First, a higher interest rate implies heavier debt burden. Second, a 
monetary tightening normally produces a slowdown in economic activity. As a consequence, future profits and wages decline. Both factors attenuate the net financial position of borrowers, which makes the moral hazard problem in the borrower/lender relationship more severe. Under asymmetric information, a lower level of net worth means that the borrower has less "skin in the game", and hence, potentially, he is more prone to taking excessive risks. In the case of a failure, the borrower loses only his net worth, assuming a limited liability; it is the lender who bears the main share of the loss. On the contrary, in the case of a success, the borrower captures the entire surplus above the loan repayment amount. The net worth of a borrower thus plays the role of a disciplining device that encourages a prudent behavior. The rational reaction of lenders to a deterioration of the net worth of borrowers will be a reduction in credit. It follows that, in response to a monetary tightening in the US, internationally active US banks will cut lending to the US firms and expand on their crossborder lending activities. Similarly, non-US banks will rebalance their loan portfolios away from loans to the US borrowers and towards to home borrowers. As in the case of the bank funding channel, the strength of the effect on domestic lending will vary across banks and depend on the exposures of home banks to cross-border lending.

\section{Methodology}

\subsection{Average effect of changes in monetary policy on bank lending}

Two directions of transmission are considered, inward and outward. For each of the two directions, two separate sets of fixed effects panel regressions are estimated. One set of regressions estimate the average effect of changes in monetary policy on lending growth:

$$
\begin{aligned}
\Delta L_{i t}= & \beta_{0} \Delta M P_{t}+\beta_{1} \Delta M P_{t-1}+\beta_{2} \Delta M P_{t-2}+\beta_{3} \Delta M P_{t-3}+ \\
& \text { macro controls } t+\text { bank controls } \text { mat-1 }_{i}+u_{i}+\epsilon_{i t}
\end{aligned}
$$

with the cross-section index $i$ corresponding to a bank. The data used in this multi-country study cover the time interval between 2000 and 2015 at quarterly frequencies. The key explanatory variables are the contemporaneous and lagged values of $\Delta M P_{t}$, which is a proxy for a change in the stance of monetary policy. For outward direction, the dependent variable is the growth rate of loans to private non-financial borrowers that domestic banks extend cross-border or their foreign affiliates, branches or subsidiaries, locally. For inward direction, the dependent variable is the growth rate of loans that domestic non-financial private borrowers obtain from domestic banks as well as foreign banks' branches and subsidiaries. 
Macro controls include proxies for the business cycle conditions at home and abroad such as output gap and inflation. The inward regressions control for monetary conditions in the home country, while the outward regressions control for monetary conditions in the foreign country. One more global macro control variable in specification (1) is the so-called Volatility Index, or VIX, a marketbased measure of uncertainty, a.k.a. the "fear index." This index is backed out from the price of option contracts on the Standard and Poor 500 stock market index, which are traded on the Chicago Board Options Exchange (CBOE). Higher values of VIX signal a higher cost of insurance against risk, which typically occurs at the times of high uncertainty or low tolerance toward risks.

Bank control variable includes such variables as the Tier 1 capital ratio defined as the ratio of a bank's capital to the value of risk-weighted assets according to the Basel Committee methodology, liquid assets, such as cash and securities - as a fraction of total assets, the logarithm of total assets in constant prices, and core deposits as a fraction of total assets.

Specification (1) is, essentially, a distributed lag regression of the loan growth at the bank level on changes in monetary policy, controlling for macro and bank-specific factors. The coefficients of interest, $\beta_{0}, \beta_{1}, \beta_{2}$, and $\beta_{3}$, measure, respectively, the effect of a unit change in the monetary policy stance on impact, in one, two, and three quarters. The sum of the coefficients $\beta_{0}+\beta_{1}+\beta_{2}+\beta_{3}$ shows the average cumulative effect on the growth in loans across banks over one year (four quarters). The hypothesis of interest is $H_{0}: \beta_{0}+\beta_{1}+\beta_{2}+\beta_{3}=0$. Its rejection at conventional significance levels would imply, in the case of inward (outward) transmission, that the cumulative effect of a unit change in foreign (domestic) monetary conditions on the growth in domestic lending (cross-border lending by domestic banks and local lending by their foreign affiliates) is statistically different from zero on average across banks.

Specification (1) though does not take into account heterogeneity across banks in terms of their exposures to cross-border activities and is therefore not informative with regard to which channel of international transmission, if present, is more important quantitatively. For example, suppose that Bank A has some cross-border liabilities denominated in the US dollars but not assets whereas Bank B holds some dollar-denominated assets but not liabilities. Then the balance sheet of Bank A will be involved in the working of the bank funding channel while the balance sheet of Bank B into the working of the portfolio channel. A monetary tightening in the US will make the US dollar funding for Bank A more expensive forcing it to cut on cross-border borrowings with the negative effect on domestic lending. In the face of a deterioration of the net worth of the US borrowers caused by the monetary tightening, Bank B will instead rebalance its loan portfolio toward domestic clients thus making a positive contribution to the credit growth at home. Obviously, the effect on Bank A and on Bank B work in the opposite directions. The aggregate effect, as estimated by regression (1), can be 
of any sign. Its value depends on what is more prevalent in the data, cross-border borrowing or cross-border lending by domestic banks. In order disentangle the two different channels, one needs to account for heterogeneity at the bank level in terms of international exposures. This is what is discussed next. Before that a few comments on how monetary stance is measured are in order.

\subsection{Measuring the stance of monetary policy}

There is no single universally acceptable measure of monetary policy, especially, for the time period when short-term interest rates, which are directly controlled by central banks and which served as the main monetary policy tool in the past, remained close to zero (i.e. at the so-called Zero Lower Bound of interest rates, ZLB) in the aftermath of the Global Financial Crisis (GFC) in the US and, later, in the euro zone. New previously untested unconventional policy tools were tried such as largescale purchases of long-term government securities by the central bank, known as the Quantitative Easing (QE). One more policy tool that many central banks started to use since recently is the so-called Forward Guidance (FG), by which the central bank communicates to market participants the intended time path of the short term policy rate depending on future developments in the economy. To the extent that long-term interest rates are influenced by market expectations of future short-term rates, FG can be, in principle, a powerful policy instrument.

Provided that measuring the stance of monetary policy is not always straightforward, it is common in the literature to employ a set of alternative proxies picking one as the baseline and using the rest for robustness checks. One possible choice could be the short-term policy rate such as the Federal Funds Rate in the US. Given that the policy rate in the US, one of the four systemic countries, was at the ZLB for about a half of time observations, such an option does not look very attractive as, over this period of the almost zero policy rate, the monetary policy in the US was more accommodating in some times and less accommodating in some other times. One smart alternative to the raw policy rate - the so-called short-term shadow rate (SSR) - was developed in Krippner (2014) and Wu and Xia (2016). The shadow rate coincides with the policy rates in the periods when the policy rates are not in the proximity of the zero mark. When the actual rate is close to zero then the shadow rate is assumed taking on negative values and being unobserved directly. As shown in Krippner (2014) and Wu and Xia (2016), its time path can be estimated structurally using a conventional affine model of the term structure of interest rates as a theoretical framework and market yield data for bonds with different maturities. Effectively, the estimation of the shadow rate takes into account the information on long-term interest rates (bond yields) that were directly targeted by the QE. The time path of the estimated shadow rate in the US is shown on the upper panel of Figure 1. One line corresponds to the Krippner estimate and the other to $\mathrm{Wu}$ and Xia's. 
Figure 1. The time path of the estimated shadow rate in the US and monetary policy shock
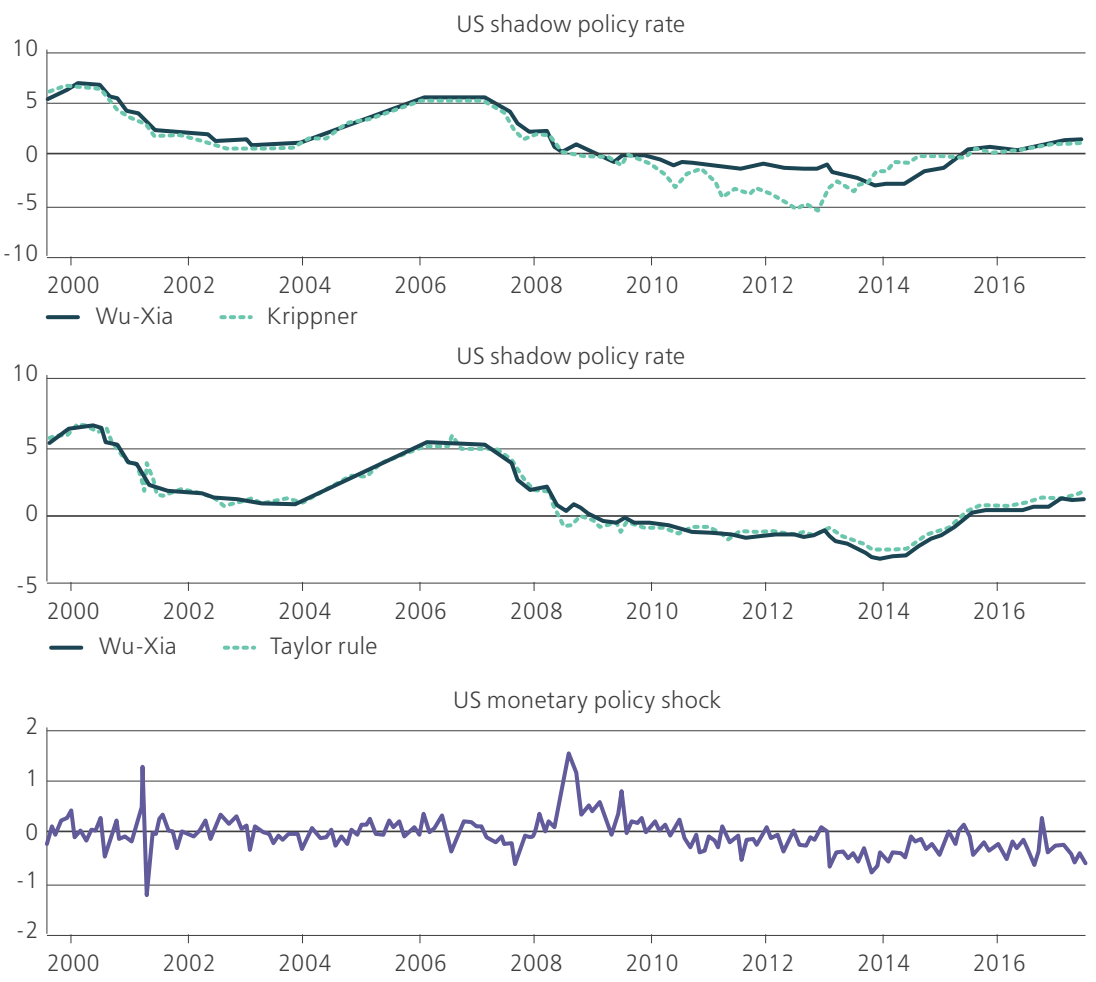

The estimates of shadow rates are sensitive to the assumptions of the underlying term structure model. This model can well be misspecified, and the estimated shadow rates themselves biased. A simpler and presumably safer alternative to the structural approach would be to have two proxies for monetary policy stance in a single equation. One proxy, the conventional short-term policy rate, characterizes monetary policy in normal times, i.e., when the ZLB constraint is not binding. The other one, the growth rate of the balance sheet of the central bank serves as a description of monetary policy in abnormal time when the policy rate stays close to zero for a long period of time. Technically, that means that the distributed lag of the growth rate of the central bank's balance sheet interacted with the ZLB dummy ZLB enters the right-hand-side of regression (1) as additional regressors:

$$
\begin{gathered}
\Delta L_{i t}=\beta_{0} \Delta M P_{t}+\beta_{1} \Delta M P_{t-1}+\beta_{2} \Delta M P_{t-2}+\beta_{3} \Delta M P_{t-3}+ \\
\gamma_{0} Z L B_{t} \times \Delta U M P_{t}+\gamma_{1} Z L B_{t} \times \Delta U M P_{t-1}+\gamma_{2} Z L B_{t} \times \Delta U M P_{t-2}+\gamma_{3} Z L B_{t} \times \Delta U M P_{t-3}+ \\
\text { macro controls }_{t}+\text { bank controls }_{i t-1}+u_{i}+\epsilon_{i t}
\end{gathered}
$$

where the $Z L B_{t}$ equals 1 if the ZLB constraint is binding in period $\mathrm{t}$ and 0 otherwise; the conventional monetary policy indicator $\Delta M P_{t}$ is a change in the 
policy rate or the shadow rate; the unconventional monetary policy indicator $\Delta U M P_{t}$ is the growth rate of the central bank's balance sheet in period $t$.

One concern with using policy rates or shadow rates in first differences is that they are likely to be endogenous regressors. For example, when the economy enters a recession, the central bank will loosen monetary policy by cutting rates and/or pumping liquidity into the market through long-term assets purchases. At the same time, the credit growth will be slowing because of lower demand for credit from borrowers and more severe standards of lending by banks. If one wants to estimate a causal effect of monetary policy changes on lending, one needs to isolate the socalled exogenous component in the variability of monetary policy, i.e. unrelated to developments in the economy and the market for loans. The exogenous component of monetary policy is also known as monetary policy shocks. A monetary policy shock that arrives on date $t$ is commonly interpreted the difference between the value of the monetary policy instrument, e.g., the policy rate, and its value prescribed by a monetary policy rule that serves as a parsimonious description of the conduct of monetary policy (Christiano et al., 1999). A simple monetary policy rule, a.k.a. Taylor rule, states that through inflation targeting central bank raises the policy rate when the rate of inflation is above the central bank's target and/or the output is above the potential:

$$
i_{t}=\rho+\pi^{*}+\varphi_{\pi}\left(\pi_{t}-\pi^{*}\right)+\varphi_{y}\left(y_{t}-y_{t}^{*}\right)+\varepsilon_{t}
$$

where $\rho>0$ is a constant parameter, $\pi^{*}$ the inflation target, $y_{t}^{*}$ the natural (potential) rate of output. The error term $\varepsilon_{t}$ on the right-hand side of (3) is monetary policy shock. The middle panel of Figure 1 shows a time path of the $\mathrm{Wu}$ and Xia's shadow rate and an estimated Taylor rule for the US. The bottom panel of Figure 1 shows a time path of the identified monetary policy shock in the US, which is the difference between those two time series.

One way to isolate the exogenous components in the changes of monetary policy is to add macro variables to the right hand side of the credit growth regressions (1) and (2) thus controlling for the state of aggregate economy to which monetary policy responds. As an alternative, one could estimate the Taylor rule (3), take the OLS residuals as proxies for monetary policy shocks, and use them in (1) and (2) in place of raw policy rates or shadow rates. The implicit identifying assumption is that the monetary policy responds to unanticipated changes in economic activity and inflation within a quarter whereas output and inflation respond to shifts in the stance of monetary policy with a delay.

In practice, though, policy makers make their decisions based on the analysis of much richer arrays of information than just two indicators, output and inflation, that appear in the Taylor rule (3), including expert judgment. For this reason, virtually any estimate of monetary policy shocks is vulnerable to an estimation bias. The academic debate on what is the most reliable way to identify and estimate monetary policy shocks is still unsettled (Ramey, 2016). Perhaps, the best way to 
proceed is to pick one specific proxy for monetary policy shocks as the baseline indicator, and use others available proxies for robustness checks. This is exactly the route that was taken in the multi-country IBRN study on international transmission of monetary policy.

\subsection{Bank-specific effects of changes in monetary policy on bank lending}

The second set of fixed effects panel regressions allows the effect of changes in monetary policy on credit growth be heterogeneous across banks and depend on bank international exposures.

As before, for the inward direction, the dependent variable is the quarterly growth rate of home bank's loan portfolio. The regressors of interest are the distributed lag of the change in the foreign monetary policy of order 3 interacted with the fourth lag of a variable that is related to a specific channel of international transmission, the so-called channel variable, $C_{i, t-4}$ :

$$
\begin{gathered}
\Delta L_{i t}=\beta_{0} C_{i, t-4} \times \Delta M P_{t}+\beta_{1} C_{i, t-4} \times \Delta M P_{t-1}+\beta_{2} C_{i, t-4} \times \Delta M P_{t-2}+\beta_{3} C_{i, t-4} \times \Delta M P_{t-3}+ \\
\delta C_{i, t-4}+\text { bank controls } i_{i, t-1}+v_{t}+u_{i}+\epsilon_{i t}
\end{gathered}
$$

For example, the loan portfolio of a bank with a greater exposure to crossborder funding as measured by the fourth lag of the ratio of cross-border liabilities to total assets is presumably more sensitive to spikes in the foreign policy rates or shadow rates, which suggests that the coefficients on the interaction terms, $\beta_{0}, \beta_{1}$, $\beta_{2}$, and $\beta_{3}$, should be negative.

The specification (4) contains both bank and time fixed effects. Time fixed effects absorb the effect of all time-varying macroeconomic factors that have a homogeneous effect on bank lending. In particular, they control for economic conditions at home and abroad. The inclusion of macro controls as in regressions (1) and (2) would be redundant as this would lead to a multicollinearity problem.

The hypothesis of interest is $H_{0}: \beta_{0}+\beta_{1}+\beta_{2}+\beta_{3}=0$. The rejection of $H_{0}$ at conventional significance levels along with the negative (positive) sign of the point estimate of $\beta_{0}+\beta_{1}+\beta_{2}+\beta_{3}$ can be viewed as evidence supporting the claim that a greater international exposure of a bank as measured by the respective channel variable, $C_{i, t-4}$, makes the negative effect of foreign monetary policy shocks on the growth of this bank's loan portfolio more (less) pronounced. In a sense, the effect of a unit foreign shock on the growth rate of loan portfolio of a bank with international exposure $C_{i, t-4}$ equals, up to an additive constant, $\beta_{0} C_{i, t-4}$ on impact, $\beta_{1} C_{i, t-4}$ next quarter, $\beta_{2} C_{i, t-4}$ in two quarters, and $\beta_{3} C_{i, t-4}$ in three quarters, with the one-year cumulative effect equal to $\left(\beta_{0}+\beta_{1}+\beta_{2}+\beta_{3}\right) \times C_{i, t-4}$. 
The specification with both conventional and unconventional monetary policy instruments that accommodates heterogeneous response of bank domestic lending to changes in foreign monetary policy depending on a bank's international exposures, an extension of (2), is

$$
\begin{gathered}
\Delta L_{i t}=\beta_{0} C_{i, t-4} \times \Delta M P_{t}+\beta_{1} C_{i, t-4} \times \Delta M P_{t-1}+\beta_{2} C_{i, t-4} \times \Delta M P_{t-2}+\beta_{3} C_{i, t-4} \times \Delta M P_{t-3}+ \\
\gamma_{0} C_{i, t-4} \times Z L B_{t} \times \Delta U M P_{t}+\gamma_{1} C_{i, t-4} \times Z L B_{t} \times \Delta U M P_{t-1}+ \\
\gamma_{2} C_{i, t-4} \times Z L B_{t} \times \Delta U M P_{t-2}+\gamma_{3} C_{i, t-4} \times Z L B_{t} \times \Delta U M P_{t-3}+ \\
\delta C_{i, t-4}+\text { bank controls } s_{i, t-1}+v_{t}+u_{i}+\epsilon_{i t}
\end{gathered}
$$

The interpretation of coefficients on double and triple interactions is similar to that in the case of regression (4).

As before, for outward transmission, the dependent variable is the growth rate of cross-border lending by home banks or local lending by their foreign affiliates. The relevant channel variables are those that characterize the extent to which domestic funding sources of a bank are sensitive to changes in the policy rate (core deposits as a fraction of total assets, short term funding ratio), the availability of liquidity buffer (liquid asset ratio), or spare risk-bearing capacity of a bank (tier 1 ratio).

\section{Summary of findings}

The paper by Buch et al (2017) provides the meta-analysis of findings of individual country studies, offering the bird's-eye view on multi-country evidence of international transmission. In what follows I summarize empirical results, first, on the inward transmission and, next, on the outward transmission. In the discussion of inward transmission, I will focus only on the effects of monetary policy changes in the US.

\subsection{Country evidence on inward transmission}

\section{Switzerland (Auer et al., 2017)}

For Switzerland, an increase in the US federal funds rate by 1 p.p. accelerates the one-year cumulative growth in credit by 0.5 p.p. whereas the effect of the unconventional monetary policy is statistically insignificant. This suggests that the bank funding channel does not play a dominant role. Regressions (4) and (5), which isolate the contribution of the two channels lead, to mixed results. With regard of the bank funding channel, evidence is counterintuitive: in response to monetary tightening in the US domestic lending by Swiss banks rises rather than falls. Auer et al (2017) explain this by the fact that the lion's share of the USD-denominated funding of Swiss banks comes in the form of cross-border 
borrowings from foreign banks rather than retail deposits and that the bank funding channel is a relevant mechanism with regard to the latter and to the former. There is evidence on the portfolio channel: Swiss banks with cross-border holdings of the US assets respond to monetary tightening in the US by an increase in domestic lending. Quantitatively, the effect is not very large, though. If the ratio of the US assets to total assets changes from 25th to 75th percentile, the size of the effect changes by only 0.10 p.p., which is small compared, for example, with the mean lending growth of $4.5 \%$ in the sample.

\section{The United Kingdom and Hong Kong (Hills et al., 2017)}

In the UK, no evidence is found in support of working of the funding channel with regard to lending to households and firms. The international exposure of a bank to cross-border finance does not affect the sensitivity of domestic credit growth to foreign monetary shocks. The portfolio rebalancing channel is present and quantitatively important: if cross-border claims to the US assets of a UK bank rise by 10 p.p. as a fraction of total assets, the positive effect of a monetary tightening in the US by 1 p.p. on domestic lending growth gets higher by 3 p.p.

The banking sector in Hong Kong is dominated by subsidiaries of foreign banks. Those subsidiaries whose parents are less dependent on the wholesale funding as measured by the deposit-to-asset ratio tend to be less sensitive to changes in monetary policy in the respective country in terms their domestic lending in Hong Kong. In the era of the unconventional monetary policy (UMP), an increase in the assets of the central bank in the parent's country as a fraction of GDP by 1.85 p.p. has a positive effect on lending by domestic subsidiaries, which is by $3.7 \%$ higher in the case of the parent bank with the deposit-toasset ratio one standard deviation below the sample average as compared with the average bank. The effect of QE is thus more pronounced for subsidiaries whose parents are more reliant on wholesale funding. There is also evidence for the working of the portfolio rebalancing channel: in response to monetary tightening in the home country of the parent, the lending growth by its Hong Kong subsidiary accelerates.

\section{Austria and Germany (Loeffler et al., 2017)}

For Austria, there is no evidence in support of the bank funding channel.

For Germany, the size of the negative effect of a rise in the cost of USD funding on domestic lending does depend on the reliance of a bank on USD funding, the respective regression coefficient being statistically significant. Quantitatively, though, the effect is not important. 


\section{France and Italy (Schmidt et al., 2017)}

For France, both bank funding channel and the portfolio rebalancing channel are at work. A French bank with the USD funding dependency ratio of $10.7 \%$, which is the sample mean, will reduce domestic lending in US dollar by $3.8 \%$ following a rise of the US policy rate by 1 p.p. The effect is economically significant. Regressions for the portfolio rebalancing channel find statistically and economically significant effect of the US monetary policy changes on a bank holding foreign securities. The sign of the effect, however, is not as expected. The ratio of foreign securities to total assets of $1.46 \%$, which is the sample mean, implies a negative, not positive effect on lending of -0.5 p.p. due to a monetary tightening in the US by 1 p.p.

Italian banks with cross-border liabilities in the US dollars do contract their lending in response to a monetary tightening in the US. It is remarkable that the effect is statistically and economically significant for euro-denominated loans whereas it is insignificant for dollar-denominated loans. There is no evidence found in support of the portfolio rebalancing channel.

\section{Ireland and Portugal (Barbosa et al., 2017)}

The lending of Irish banks with higher net cross-border liabilities to the US is found to be more sensitive to the US monetary policy changes. Higher liquid asset holdings, on the contrary, tend to mitigate the negative effect of the US monetary tightening. Overall, the estimated effects are rather weak quantitatively, although using Taylor rule residuals as proxies for monetary policy changes makes them somewhat stronger. Irish banks with larger holdings of the US assets increase their lending at home following a monetary tightening in the US, which is consistent with the portfolio rebalancing channel of transmission. This effect disappears in specifications with Taylor rule residuals.

\section{Chile, Korea, and Poland (Gajewski et al., 2017)}

The effect of changes in the US monetary policy is found to be amplified by cross-border liabilities of banks in Chile and Korea. In Poland, liquid asset holdings are shown have a mitigating effect. The evidence in support of the international portfolio rebalancing channel is found for Korea.

\section{Russia (Kruglova et al., 2018)}

Some evidence is found in support of the view that the effect of the U.S. monetary policy shocks was statistically significant and sizable most of the 2000s and became muted more recently, which coincided with monetary policy transiting from exchange rate to inflation targeting. The time series of the US 
monetary policy shocks is constructed as the time path of Taylor rule residuals of the US shadow policy rate. This documented pattern is consistent with the theoretical prediction that, under free floating, the economy is more insulated from the influence of foreign monetary policy shocks, although geopolitical factors can also be a part of the reason.

\subsection{Country evidence on outward transmission}

\section{Canada (Auer et al., 2017)}

For Canada, the average effect of domestic monetary tightening on crossborder lending by Canadian banks is statistically insignificant. One interpretation is that a negative contribution of the bank funding channel is offset by a positive contribution of the portfolio rebalancing channel. Banks with higher ratios of short-term deposits to total assets are more sensitive to changes in monetary policy in Canada. The effect is quantitatively significant. A bank with the short term deposit funding ratio at 75 th percentile will reduce its cross-border lending by 16.09 p.p. more than a bank with this ratio at 25th percentile. Exploiting the Tier 1 Capital Ratio as a proxy for the funding channel also delivers statistically and economically significant results: the cross-border lending of banks with higher Tier 1 Ratios is less sensitive to changes in the domestic monetary tightening since well capitalized banks have a better access to relatively cheap wholesale funds. There is no evidence in support of the importance of the portfolio channel if one uses the Canadian policy rate as an indicator of the monetary policy stance. Specifications with Taylor rule residuals, which serve as proxies for the monetary policy shock, or an unexpected component of changes in monetary policy, speak in favor of the portfolio channel. Banks with higher shares of securities in assets and higher shares of cross-border loans in totals assets are less sensitive to domestic monetary policy shocks in term of foreign lending.

\section{Austria and Germany (Loeffler et al., 2017)}

No evidence is found in support of the hypothesis that monetary policy changes in the euro area affect cross-border lending by Austrian and German banks.

\section{The Netherlands, Spain, and the United States (Argimon et al., 2017)}

The outward transmission of monetary policy changes in the home country is considered separately for cross-border lending by home banks and for local lending by foreign affiliates of home banks in host countries. 
For the Netherlands, a higher liquid-to-total-asset ratio tends to mitigate the negative effect of monetary policy changes in the euro zone on the growth of local lending by foreign affiliates by Dutch banks although the overall effect on lending growth is statistically insignificant for the median bank. Similarly, the effect of changes in home monetary policy on cross-border lending is less pronounced for larger banks as measured by the logarithm of total assets in real terms. The latter finding may reflect the ability of larger banks to access cheaper sources of wholesale funding. For Spain, banks with higher short-term wholesale funding ratios experience lower growth rate of local lending by their foreign affiliates following a monetary tightening in the euro zone whereas the effect on cross-border lending is weaker for banks with higher liquid asset ratios and for larger institutions. There is also evidence of the bank funding channel for the US, although the estimated effects are quantitatively small. The economic significance of the international portfolio rebalancing channel of transmission seems also limited.

\section{Overall cross-country meta-analysis (Buch et al., 2017)}

Inward transmission was documented in all individual country studies. Outward transmission works through cross-border lending by global banks or local lending by foreign affiliates. Inward transmission of the US monetary policy changes is found for almost all countries. The most typical determinants of heterogeneous responses of bank lending to changes in monetary policy seem to be cross-border asset and liability holdings. The effect is relatively more important quantitatively for financially open economies and emerging markets.

It is worth noting, though, that the explanatory power of bank-specific variables capturing heterogeneous impact of monetary impulses on lending is rather limited as indicated by moderate improvements in adjusted R-squared. This suggests that international flows of credit to private non-financial borrowers are unlikely to jeopardize financial stability unlike interbank loans and/or securities.

\section{References}

Argimon, I., Bonner, C., Correa, R., Duijm, P., Frost, J., de Haan, J., de Haan, L. and Stebunovs, V. (2017). Financial institutions's business models and the global transmission of monetary policy. Bank of Spain Working Paper, №1815.

Auer, S., Friedrich, C., Ganarin, M., Paligorova, T. and Towbin, P. (2018). International monetary policy transmission through banks in small open economies. Swiss National Bank Working Paper, 4.

Barbosa, L., Bonfim, D., Costa, S. and Everett, M. (2017). Cross-border spillovers of monetary policy: What changes during a banking crisis? Mimeo. 
Buch, C., Bussiere, M., Goldberg, L. and Hills, R. (2018). The international transmission of monetary policy. Federal Reserve Bank of New York Staff Reports, № 845.

Christiano, L., Eichenbaum M. and Evans C. (1999). What have we learned and to what end? In: Woodford M. and Taylor J., Eds. Handbook of Macroeconomics. Amsterdam: Elsevier, pp. 65-148.

Gajewski, K., Jara, A., Kang, J., Mok, J., Moreno, D. and Serwa D. (2017). International bank lending channel of monetary policy: Lessons from Chile, Korea, and Poland. Mimeo.

Hills, R., Ho, K., Reinhardt, D., Sowerbutts, R., Wong E. and Wu, G. (2017). The international transmission of monetary policy through finance centers: Evidence from the United Kingdom and Hong Kong. Hong Kong Monetary Authority Working Paper, 25.

Krippner, L. (2016). Documentation for measures of monetary policy. Mimeo.

Kruglova, A., Styrin, K. and Ushakova, Yu. (2018). Inward transmission of foreign monetary policy shocks to a small open economy in the presence of country-specific shocks: The case of Russia. Mimeo.

Loeffler, A., Segalla, E., Valitova, G. and Vogel, U. (2017). International monetary policy spillovers through the bank funding channel. [Deutsche Bundesbank and Oesterreichische Nationalbank].

Ramey, V.A. (2016). Macroeconomic shocks and their propagation. In: Taylor J. and Uhlig H., Eds. Handbook of Macroeconomics. Amsterdam: Elsevier, pp. 71-162.

Schmidt, J., Caccavaio, M., Carpinelli, L. and Marinelli, G. (2017). International spillovers of monetary policy: Evidence from France and Italy. Mimeo.

Wu, C. and Xia, F. (2016). Measuring the macroeconomic impact of monetary policy at the zero lower bound. Journal of Money, Credit and Banking, 48 (2-3), pp. 253-291. 